\title{
起業と経営の現場から ジエンダーを考える
}

秋山咲恵

2013年に発足した第二次安倍内閣では、「女 性活躍推進」を重要な政治課題として位置付け ており、総務省の労働力調查において女性の就 業率が 50 年ぶりに $50 \%$ を超えるなどいくつか

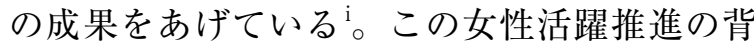
景にあるのは、世界的な人権意識の高まりのみ ならず、日本が直面している少子高齢化による 人口減少、とりわけ労働人口の減少による経済 の減縮への危機感である。

1999年に“ウーマノミクス”という考え方が 提唱されて 20 年が経過し、ジェンダーダイバー シティ推進が経済効果をもたらすことが広く認 識されるようになった結果、経済界における女 性を取り巻く環境は着実に変化しつつある ${ }^{\mathrm{ii}}$ 。

特に企業統治の観点から、重要な意思決定の 場である取締役会におけるダイバーシティ推進 策として女性役員、特に女性の独立社外取締役 の登用が進むなど、経営の現場においてはジェ ンダー平等の浸透は着実に進んでいる。

しかしながら、それでもなお日本の現状は世 界の潮流にキャッチアップしているとは言え ず、多くの課題を抱えたままである。これらの 課題解決に向けて、科学はどのように社会に寄 り添っていけるのだろうか。

1985年に制定された「雇用の分野における 男女の均等な機会及び待遇の確保等に関する
法律」（通称：男女雇用機会均等法）により、 1986 年の大企業の採用活動において総合職と 呼ばれる幹部候補生へのキャリアにつながる門 戸が、女子学生にも開かれることとなった。私 自身がこの年の就職活動を経て社会人としての スタートを切る「幸運に恵まれた」。というのも、 それまでは社会の入り口となる就職活動におい て、民間企業では男女別に選考されることが当 たり前であり、私のいた京都大学法学部におい ても女子学生の進路は国家試験や公務員が中心 であり、民間企業への就職は極めて稀だったか らである。当時はバブル景気の最終盤の時期で もあり、経済状況も導入の追い風になっていた のではないかと推察する。

私自身は、民間企業への就職の後、1994年 に起業の道を選んだ。起業については、当時抱 いていた問題意識を事業化することが目的で あったが、同時に“結婚生活と仕事を両立する” という、当時直面していた個人的な課題を克服 する手段として、夫と一緒に起業するという生 き方、働き方を選んだという側面もあった。

まだまだ稀少な存在である女性の起業家、そ れも先端技術開発型の製造業の分野で世界市場 に打って出たという起業の実績を評価されて、 2003 年内閣総理大臣の諮問機関である政府税 制調査会の委員を委嘱され、当時女性かつ最年 少の委員として議論に加わることとなった。こ 
れは、当時の小泉純一郎総理による「政府の会 議には女性を $30 \%$ 以上参加させるべき」とい うアファーマティブアクションの指示が契機と なったものである。国の審議会等委員に占める 女性委員の比率は平成の初めにはまだ $8 \%$ 程度 であったが、 2003 年時点で $26.8 \%$ となり、さら


男性であったなら決して得られなかった機会を 得た意味を考えると、次世代に確実に繋いでい くべきバトンとして、審議会等の仕事にも誠実 に取り組んできた。

日本の女性活躍を中心としたジェンダーの取 り組みは世界からも注目されている。

IMF（国際通貨基金）が日本の GDPは人口 動態の影響により 40 年後に $25 \%$ 縮小すると警 鐘を鳴らし、その打開策として女性活躍推進を 含む構造改革の必要性をあげている。

ここでは、女性の賃金が男性の4分の3であ るという男女賃金格差は、先進7カ国（G7）に おいて最大の格差であるとも指摘されている。 ラガルド専務理事は、「しかしこうした政策が 成功するには女性のエンパワーメントが文化の 一部として根付き、働く女性に対する人々の姿 勢にも浸透しなければなりません。経済活動に 参加する女性たちは、社会共通の利益のために 優れた才能を発揮しているのですから。そのた めには社会・文化の障壁も取り払わないといけ ません。男性も男女平等のために力を合わせ、 見識を共有し、喜びも苦労も分かち合い、お互 いの才能を存分に発揮できるように刺激し合う
PROFILE ヤ

秋山咲恵（あきやま さきえ）

ロ株式会社サキコーポレーションファウンダー ・ソニー株式会社、オリックス株式会社、日本 郵政株式会社 社外取締役

専門 経営

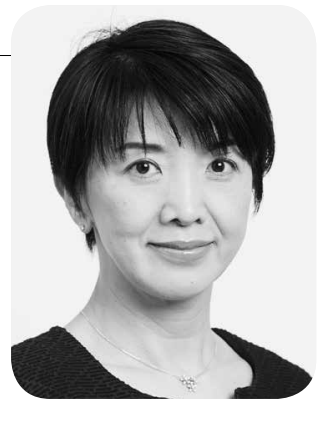

べきです」。この指摘は、示唆に富む。

ユニセフの調査によると、OECDにEUを加 えた 41 カ国中、日本は男性の育児休業に関し て最も先進的な制度を持ちながら、男性の育児 休業取得率が極めて低い実態が次のように指摘 されている。「日本は父親に 6 カ月以上の（全 額支給換算）有給育児休業期間を設けた制度を 整備している唯一の国ですが、2017年に取得 した父親は 20 人に 1 人にとどまっています」。 この事例は、社会・文化の障壁が政策の成功を 妨げている好例といえる。

この社会・文化の障壁は、現在さまざまな形 でわれわれの日常生活に拡がっている。

とりわけ社会における男女の役割分担につい ての認識のバラツキは至るところで見られる。

企業トップは女性活躍方針を打ち出している が、現場の管理職レベルの言動がまだ追いつい ていない。若いカップルの間では家事育児の分 担意識はフェアになりつつあり、親世代など高 齢者の意識とのギャップがある。経済界からは 経済合理性やグローバル経済の潮流に基づく政 策提言がなされているのに、政治の世界では過 去の価值観を大切にする人たちとの整合性を優 先している。グローバルな女性活躍の潮流を肌 で感じている人たちの発言を聞いても、どうし てもピンとこないドメスティックな生活者。

それぞれの人たちが置かれている環境によっ て認識のバラツキが大きくなっていることが原 
因であり、時代の流れが大きく変わる時に起き やすい事象であると考えられる。

男女の役割分担に関する考え方の前提となっ ている「男女差」に関して、研究の世界では、 有意な能力差はなく個人差に帰結することはす でに知られている。さらに近年、能力差ではな く特性差が有意な男女差を生み出しているとい う研究が報告されている。

その男女間で有意な差が表れる特性の一つが 競争心である。米国のスタンフォード大学の ミュリエル・ニーデルレ教授らの研究を嚆矢と して、競争的環境におかれた場合、女性は男性 よりもパフォーマンスが低くなることがわかっ ている ${ }^{\mathrm{vi}}$

これらは、米国のみならず、多くの国々で同 様の結果が示されており、日本でも同様の結果 を示す実証研究が存在する。そして、近年の研 究は、この競争心の男女差は、学力や学歴、収 入などの男女差の一部を説明することも明らか にしている。例えば、男女の賃金格差のおよそ 10\%程度は競争心の男女差で説明することがで きるという米国での研究もある ${ }^{\mathrm{vii}}$

加えて、競争心の男女差は、教育を通じた技 術や知識の獲得のあり方 $(=$ 人的資本への投資 $)$ にも影響を与える。日本では、ある自治体の公 立中学 2 年生を対象に行った実験において、競 争心が数学の学力テストの結果に影響すること が示されている。女子のほうが男子よりも算 数・数学の学力が低いことはよく知られている が、その学力格差の $9.2 \%$ から $13.5 \%$ 程度は競
争心の男女格差で説明できることがわかってい る viii。

これらの研究成果が示唆することは、これま での日本の男性中心社会の中で築かれてきたさ まざまな制度やしくみが男性の特性を最大限に 活かすように最適化されてきたのではないかと いう気づきである。競争を勝ち抜くことに重き を置いた価值観の組織や社会においては、そ の中で女性が活躍することに困難が伴うことに は、必然性があると考えられる。雇用機会均等 法施行以降に総合職 1 期生世代として苦労して キャリアを積んできた女性たちが、若い世代の 女性から「あのようにはなりたくない」と共感 を得られない面があることも理解できる。

目前に迫る少子高齢化社会において、少しで も活力を失わない社会にするためには、女性活 躍を含めたジェンダー平等に関しての社会・文 化の障壁を取り除いてゆくことが急務である。 それには、男女差に関する認識のバラツキを収 束させることが重要である。科学的なエビデン スの提示は、そのための有効な手段である。

政策や制度見直しの議論において、個人の価 值観ではなく、科学的根拠に基づく議論がなさ れること、そして合理的な対応策が立案され、 実行と科学的検証を繰り返しながら正しい方向 に進めてゆくことが時代の要請であると考え る。

私は今回、国立研究開発法人科学技術振興機 構と日本学術会議が共催するジェンダーサミッ 
ト10（以下、GS10）のフォローアップシンポ ジウムへの参画を通じて、改めてアカデミアが 社会に真摰に寄り添扮うとする姿勢に共感を覚 えた。

GS10が目指す、「性差をイノベーションの質 的向上のための重要な要素と捉えて科学のある べき姿を議論し、その成果を教育や人材育成、 基礎研究、実用化開発等に活かす」という考え 方や、ジェンダー平等が女性や女子だけではな く、男性と男子、年齢、文化、地域性、宗教な どと関連し、これらの要因との関連を重視する “Gender Equality 2.0”という概念の提案は、時 代の要請に沿うものであり、これからの成果に 期待するところである。
注

i「女性の就業率、50年ぶけ5割超す」、日本経済新聞、2019年2月. https://www.nikkei.com/article/DGXMZO40789960R00C 19A2EA2000/

労働力調查 (基本集計) 平成30年 (2018年)平均(速報)結果の 要約、総務省統計局.

https://www.stat.go.jp/data/roudou/sokuhou/nen/ft/pdf/ index1.pdf

ii「ウーマハミクス5.0 20年目の検証と提言」、ゴールドマン・サックス、 キャシー・松井、鈴木廣美、建部和礼、2019年4月.

https://www.goldmansachs.com/japan/our-thinking/ pages/womenomins-5.0/womenomics5.0.pdf

iii 国の審議会等における女性委員の参画状況調べ、内閣府男女 共同参画局、平成25年12月.

http://www.gender.go.jp/research/kenkyu/ratio/pdf/ singi251225.pdf

iv IMFラガルド専務理事インタビュー「日本GDP25\%縮小に警鐘と 打開策」、日経ARIA、2019年3月.

https://aria.nikkei.com/atcl/column/19/032500088/ 032500001/

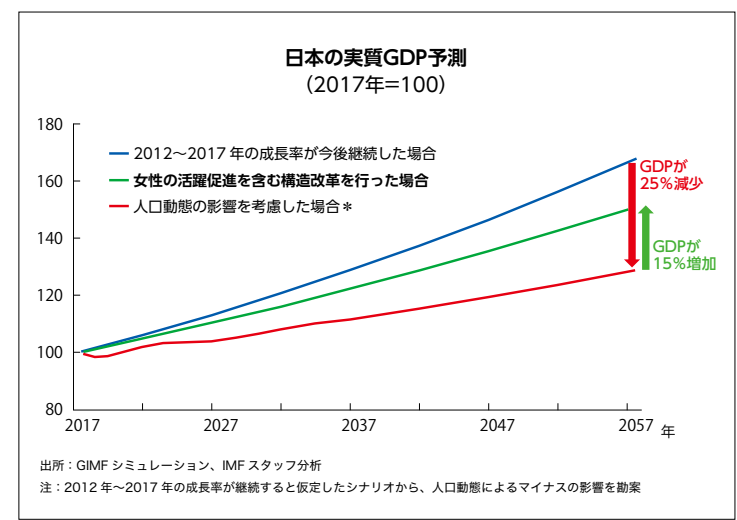

v 子育て支援策新レポート「家族にやさしい政策」で先進国を順位 付け、ユニセフ、2019年6月.

https://www.unicef.or.jp/news/2019/0087.html

vi Niederle, M., \& Vesterlund, L. (2007). Do women shy away from competition? Do men compete too much?. The quarterly journal of economics, 122(3), 1067-1101.

vii Reuben, E., Sapienza, P., \& Zingales, L. (2015). Competitiveness and the gender gap among young business professionals. mimeo.

viii Yagasaki, M., \& Nakamuro, M. (2018) Competitiveness, Risk Attitudes, and the Gender Gap in Math Achievement, RIETI Discussion Paper E-066. 